\title{
CYCLE OF WRITING PROPHECY: EXPLORING BELIEFS AND FEAR IN ACADEMIC WRITING
}

\author{
Noor Hanim Rahmat ${ }^{1 \mathrm{i}}$, \\ Mazlen Arepin', \\ Norhartini Aripin', \\ Zarina Razlan ${ }^{4}$ \\ ${ }^{1}$ Akademi Pengajian Bahasa, \\ Universiti Teknologi MARA, \\ Shah Alam, Malaysia \\ ${ }^{2}$ Faculty of Education, \\ Universiti Teknologi MARA, \\ Kampus Puncak Alam, \\ Selangor, Malaysia \\ ${ }^{4}$ Akademi Pengajian Bahasa, \\ Universiti Teknologi MARA Cawangan Johor, \\ Kampus Segamat, \\ Johor, Malaysia
}

\begin{abstract}
:
The fear of writing stems from many reasons. Some fear the process, some fear the product, while others fear the reaction given towards their writing product. Past researchers have done many studies that investigate many angles of writing. When it comes to writing, the self-imposed belief (positive or negative) is dependent on other imposed expectations (positive or negative). This in turn affects the end result of the writing assignment. This study is done to investigate the cycle of writing prophecy and explore how this cycle is influenced by the writers' beliefs and fear. 108 participants were purposely chosen from a few groups of students who registered for an academic writing course, they were asked to respond to the instrument. The instrument used is a survey (table 1). The survey has 5 sections. Section A is about demographic profile. Section B has 9 items on Beliefs. Section C has 15 items on Writing apprehension. Section B has 7 items on Behaviour, and section $\mathrm{E}$ has 25 items on result. Findings bear interesting pedagogical implications towards the teaching and learning of writing.
\end{abstract}

Keywords: writing apprehension, fear, beliefs, behaviour, result

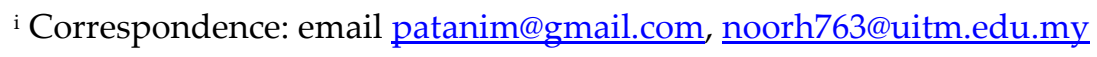




\section{Introduction}

The four language skills are usually listed in the order they are learnt in the native language- listening, speaking, reading and writing. Unlike listening and speaking skills that come almost naturally, reading and writing are taught skills. Many find writing a difficult skill even in the native language. This is because writing skills require many other processes. Some writers enjoy writing activities, while others fear all writingrelated activities.

The fear of writing stems from many reasons. Some fear the process, some fear the product, while others fear the reaction given towards their writing product. Past researchers have done many studies that investigate many angles of writing. Based on Figure 1, Rahmat (2021) found that when it comes to writing, the self-imposed belief (positive or negative) is dependent on other imposed expectations (positive or negative). This in turn affects the end result of the writing assignment.

\section{Slef-Imposed Belief \\ (Positive/Negative)}
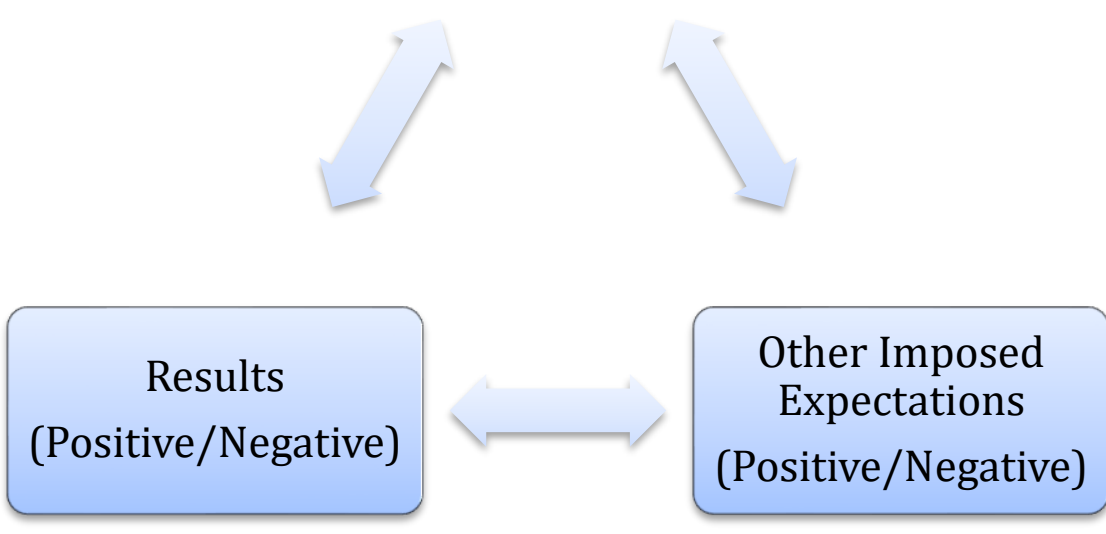

Figure 1: Model of Writers Prophecies (Rahmat, 2021)

While some may say a little bit of writing anxiety can be good, many still feel writing apprehension brings more negative related consequences. According to MarzecStawiarska (2012) \& Rahmat (2020), writing apprehension results in a negative and pessimistic attitude to writing. For some learners, some level of anxiety towards learning, pushes them to try harder to excel. Nevertheless, several studies have reported that writing apprehension can lead to negative impacts. Al-Shboul \& Huwari (2015) found that learners who had bad experience about writing in their past, end up having higher writing apprehension. In addition to that, Badrasawi, Zubairi \& Idrus (2016) also found that writing apprehension can lead to poor performance in that skill. Hence, this study is done to explore the cycle of fear in writing and how learners are coping with that. Specifically, this study is done to answer the following questions; 

1) How does writers' writing apprehension influence their beliefs?
2) How does writers' writing apprehension influence their expectations ?
3) How does writers' writing apprehension influence their behaviour?
4) How does writers' writing apprehension influence their results?

\section{Literature Review}

\subsection{Introduction}

This section presents information on self-fulfilling prophecy, writing difficulties, past studies and also the conceptual framework of this study.

\subsection{Self-Fulfilling Prophecy}

Self-fulfilling prophecy is a sociological term. It is used to describe a person's making predictions and that belief in the predictions makes it become true. The process whereby a person's expectations about something can lead to that person to behave in ways that confirms the expectations. With reference to figure 2, according to Merton (1948) and in the context of writing, when a person has beliefs about writing, this belief then influences his/her expectations. The expectations then influence his/her behaviour. This behaviour then influences the results (ie, the product of writing task).

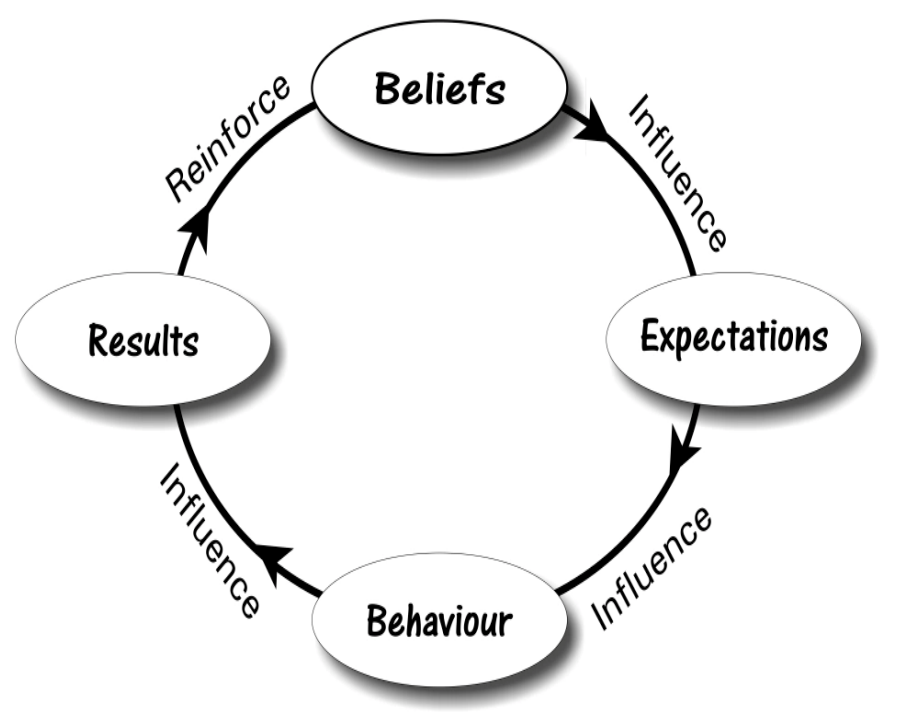

Figure 2: Self-Fulfilling Prophecy (Merton, 1948)

\subsection{Difficulties in Academic Writing}

There are many reasons why many perceive academic writing as difficult. Writing difficulties can be divided into three; (a) linguistic difficulty, (b) physiology difficulty and (c) cognitive difficulty. Linguistic difficulty refers to difficulties in grammar, vocabulary, and also language use. Next, Physiology difficulty are the difficulties that make writing difficult because the writers feel they do not have interaction from readers. Finally, Cognitive difficulty refers to the difficulties in terms of formal instruction (-eg spelling, 
punctuation, capitalization, paragraphing). In addition to that, Klimova (2014) ordered the difficulties as such;

- correct word order;

- use of articles;

- restricted range of vocabulary;

- use of formal language;

- correct spelling of English words;

- grammar structures;

- use of commas;

- finding the ways how to start their writing;

- transforming ideas from their native language into English;

- writing references and bibliography.

\subsection{Past Studies}

The anxiety for one language skill can influence the fear for another language skill. The study by Shahbaz, Rabani, \& Noor (2021)investigated classroom anxiety and its association with English writing fear and English-speaking fear in the context of The Women University, Multan (WUM). The participants were the students of WUM who enrolled in different programs including pure science, social sciences and department of languages. Data was analyzed quantitatively using SPSS and the results showed that classroom anxiety is positively correlated with English writing fear or English-speaking anxiety. Findings also showed that both anxieties (speaking and writing) exist significantly in WUM students. Furthermore, English writing fear and speaking fear were also found to be significantly correlated with each other. Thus, the present study highlights that English teacher should take significant measures to reduce the level of anxiety among students. Students need to be guided so they can overcome their English writing or speaking fear in any context of language use.

Writing apprehension can bring negative consequences to writers. The study by Al-Shboul \& Huwari (2015) explored the causes of writing apprehension among Jordanian PhD students at Universiti Utara Malaysia. This qualitative case study interviewed 21 Jordanian PhD students. Four main themes emerged. The themes are (a) Lack of knowledge in English structure, (b)Negative attitude toward writing, (c) Negative writing experience in the past, and (d) Inadequate knowledge in academic writing. The study concluded that writing apprehension was a prevalent phenomenon among the students. The study contributes to the body of knowledge on writing apprehension related to the causes of writing apprehension; highlighting both the internal and external factors which contribute to writing apprehension. Another study by Badrasawi, Zubairi, \& Idrus (2016) was conducted to further explore the teachers' and students' perceptions on the relationship between writing apprehension and writing performance, contributing factors of writing apprehension, and strategies to reduce writing apprehension. Semi-structured interviews were conducted to get more in-depth information from two respondents: one experienced instructor of teaching writing at the and another, a graduate student who was reported to having a high level of writing 
apprehension using Daly and Miller's (1975) questionnaire on writing apprehension. Thematic analysis approach was used for data analysis. Both respondents were convinced that writing apprehension has a negative influence on students' writing performance. The sources of contributing factors could be students, instructors, and teaching learning setting. Writing apprehension could be reduced through suggested strategies.

Some of the reasons why students are apprehensive about writing is because they have writing difficulties. The study by Fadda (2012) was done to determine what difficulties King Saud University students faced in academic English. It was also done to differentiate between students' learning needs and objectives when it comes to writing difficulties. The sample consisted of 50 postgraduate students. Analysis of the data showed that English as a second language (ESL) students face many difficulties and stresses in their academic writing. They have difficulty distinguishing between spoken and written English. They found it difficult to prepare outlines before writing a draft. They found it difficult to identify the skills needed for successful writing, and avoiding plague words and phrases.

1) Knowing the plague words and phrases they should avoid.

2) Reviewing the grammar in their writing.

3) Experiencing difficulty in using pronouns and maintaining pronoun-antecedent agreement.

4) Making mistakes with subject-verb agreement.

5) Making sentence fragments in their writing.

6) Experiencing difficulty when combining sentences in their writing.

Nevertheless, writers can reduce their apprehension if they can make use of proper resources to be included in their writing. The by Zhang (2019) reports on how the use of online resources based on systemic functional linguistics (SFL) impacted college students' emotional alignment with writing practices. Through qualitative analyses of inclass discussions, students' interviews and reflections, as well as their written pieces gathered in a Chinese university, the case study shows that the students were able to overcome their fears with writing construction associated with their dearth of effective knowledge. More importantly, students used the knowledge from online resources, actively and confidently. The study concludes the importance of make full use of online resources that are effectively designed and linguistically grounded to help in writing.

\subsection{Conceptual Framework}

The conceptual framework of the study is scaffolded from Merton's (1948) self-filling prophecy. The scaffolds form self-fulling prophecy is combined to explain the cycle of writing fear. The cycle of fear for writing in this study revolves around writing difficulties (Fadda, 2012; Rahmat, 2019) and writing apprehension (Cheng, 2004).

Merton's (1948) model sets the template for the framework reveals 4 important constructs; (1) beliefs, (2) expectations, (3) behaviour, and (4) result. The (1) beliefs originate from how the writer reasons why he/she finds writing difficult and the reasons can either be trace form (a) the writers' personal view of himself/herself or (b) their view 
on their writing teacher. Next, the (2) expectations become internalized due to the writer's writing apprehension, specifically; (a) somatic anxiety and (b) cognitive anxiety. The third stage is (3) behaviour. As a result of the expectations (the writing apprehension), the writer begins to (3) exhibit avoidance behaviour when it comes to writing-related activities. The last stage is (4) result. This is the stage where the writer looks at his/her written task and reflect on the language use and writing process skills.

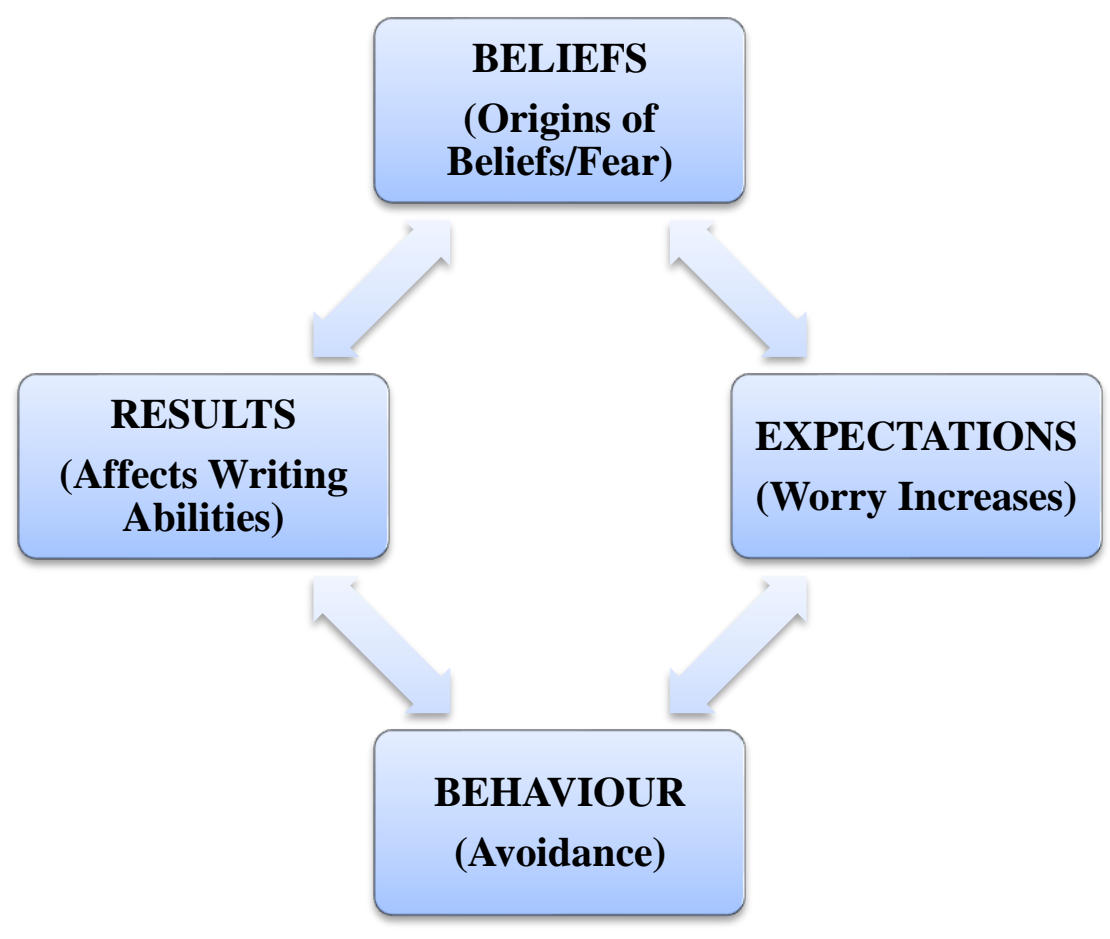

Figure 3: Conceptual Framework of the StudyCycle of Writing Prophecy: Beliefs and Fear

\section{Methodology}

This quantitative study is done to investigate the cycle of writing fear. 108 participants were purposely chosen from a few groups of students who registered for an academic writing course, they were asked to respond to the instrument. The instrument used is a survey (table 1). The survey has 5 sections. Section $A$ is about demographic profile. Section B has 9 items on Beliefs. Section C has 15 items on Writing apprehension. Section $\mathrm{B}$ has 7 items on Behaviour, and section $\mathrm{E}$ has 25 items on result.

Table 1: Distribution of Items in the Instrument

\begin{tabular}{|c|c|c|c|c|}
\hline Section & Heading & Construct & Adapted from & No of Items \\
\hline A & Demographic Profile & & & \\
\hline B & Belief & Origins of Beliefs & Fadda (2012) & 9 \\
\hline C & Expectation & SA \& CA & Cheng (2004) & $7 \& 8$ \\
\hline D & Behaviour & Avoidance & Cheng (2004) & 7 \\
\hline E & Result & Punctuation \& LU \& writing & Rahmat (2019) & 25 \\
\hline
\end{tabular}


Table 2 shows the results of reliability text on the instrument. Findings revealed a Cronbach alpha of .961, thus giving it a good internal reliability. Data is analysed using SPSS version 26 to reveal mean scores for the variables. The findings are presented in the form of bar charts.

Table 2: Reliability Statistics

\section{Reliability Statistics}

\begin{tabular}{r|r}
$\begin{array}{c}\text { Cronbach's } \\
\text { Alpha }\end{array}$ & N of Items \\
\hline .961 & 56 \\
\hline
\end{tabular}

\section{Findings}

\subsection{Introduction}

This section presents the findings by answering the research questions:

1) How does writers' writing apprehension influence their beliefs?

2) How does writers' writing apprehension influence their expectations ?

3) How does writers' writing apprehension influence their behaviour?

4) How does writers' writing apprehension influence their results?

\subsection{Findings for Beliefs}

The (1) beliefs originate from how the writer reasons why he/she finds writing difficult and the reasons can either be trace form (a) the writers' personal view of himself/herself or (b) their view on their writing teacher.

a) RQ1-Learners' Reasons -Personal

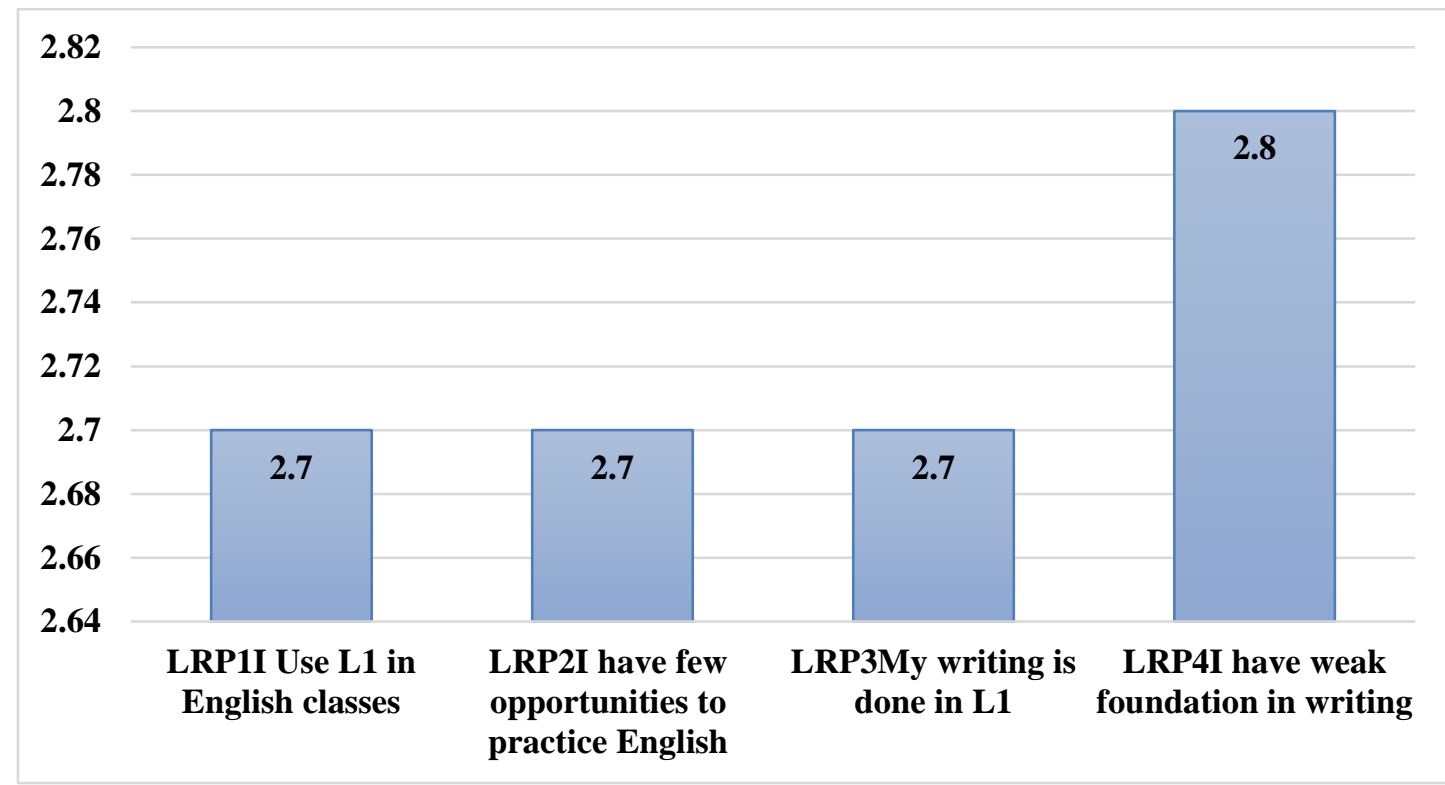

Figure 4: Mean for Learners' Reasons-Personal 
With reference to figure 4 , the highest mean is 2.8 for "writers felt they had weak foundation in writing. Respondents also reported that that "used their first language in the English classes (mean=2.7), they "had few opportunities to practice English" (mean=2.7) and also they reported to "have weak foundation in writing" (mean=2.7).

\section{b) RQ2-Learners' Reasons -Teachers}

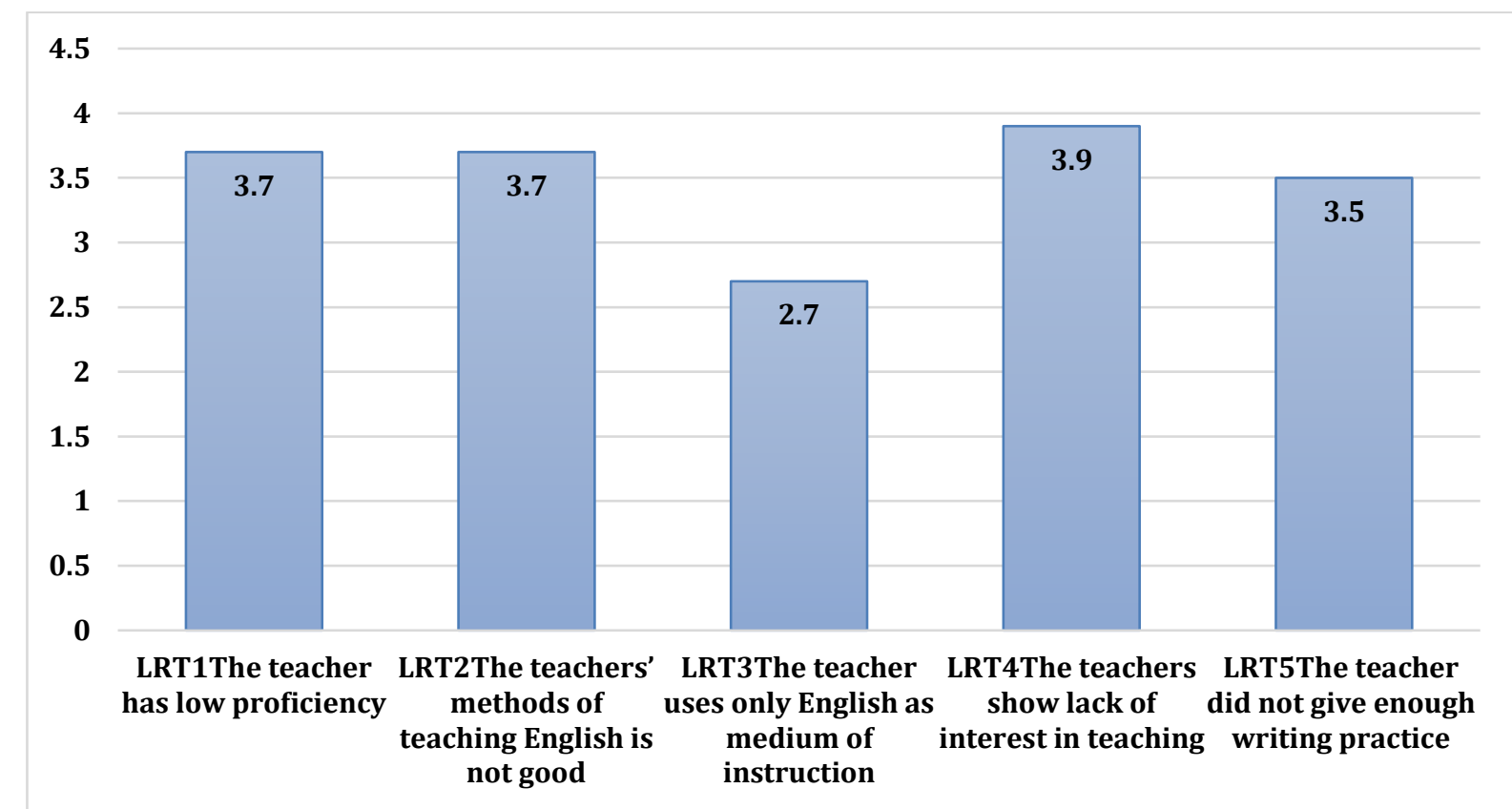

Figure 5: Mean Score for Learners' Reasons-Teachers

Figure 5 presents the mean for learners' reasons (teachers). The highest mean if 3.9 for "the teachers show lack of interest in teaching. Next, some also reported the teachers as "having low proficiency (mean=3.7). They also felt that the "teacher did not give enough writing practice (mean=3.5).

\subsection{Findings for Expectations}

The expectations become internalized due to the writer's writing apprehension, specifically; (a) somatic anxiety and (b) cognitive anxiety. 
a) Somatic Anxiety

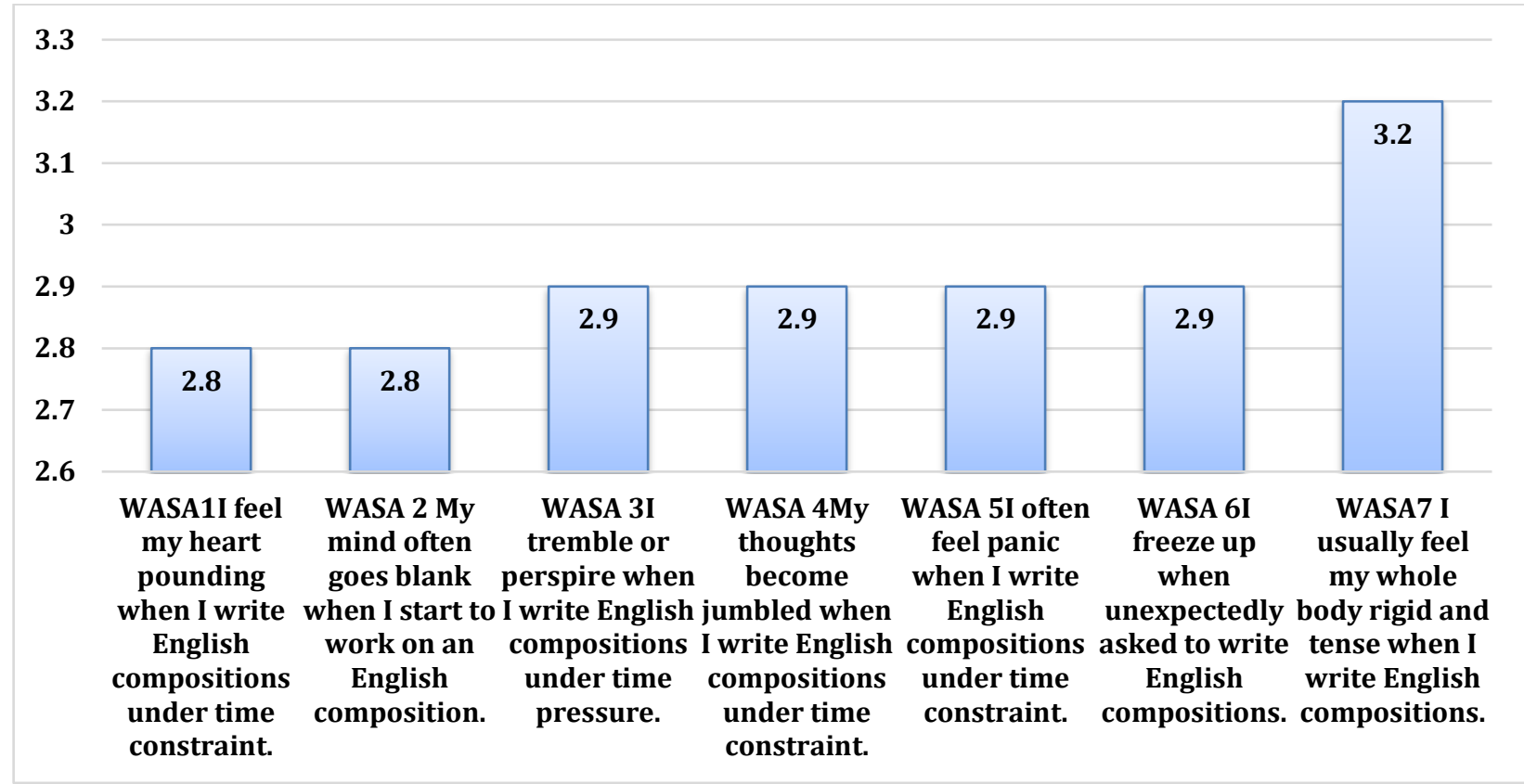

Figure 6: Mean Score for Somatic Anxiety

The mean score for somatic anxiety is presented in figure 6 above. The highest mean at 2.9 is reported for four items. Respondents reported that "they tremble or perspire when they wrote English composition". They said that their "thoughts became jumbled when they wrote English compositions under time constraint". They reported that they often "panic when they wrote English compositions under time constraints". They also "freeze up when they were unexpectedly asked to write English compositions".

b) Writing Anxiety-CA

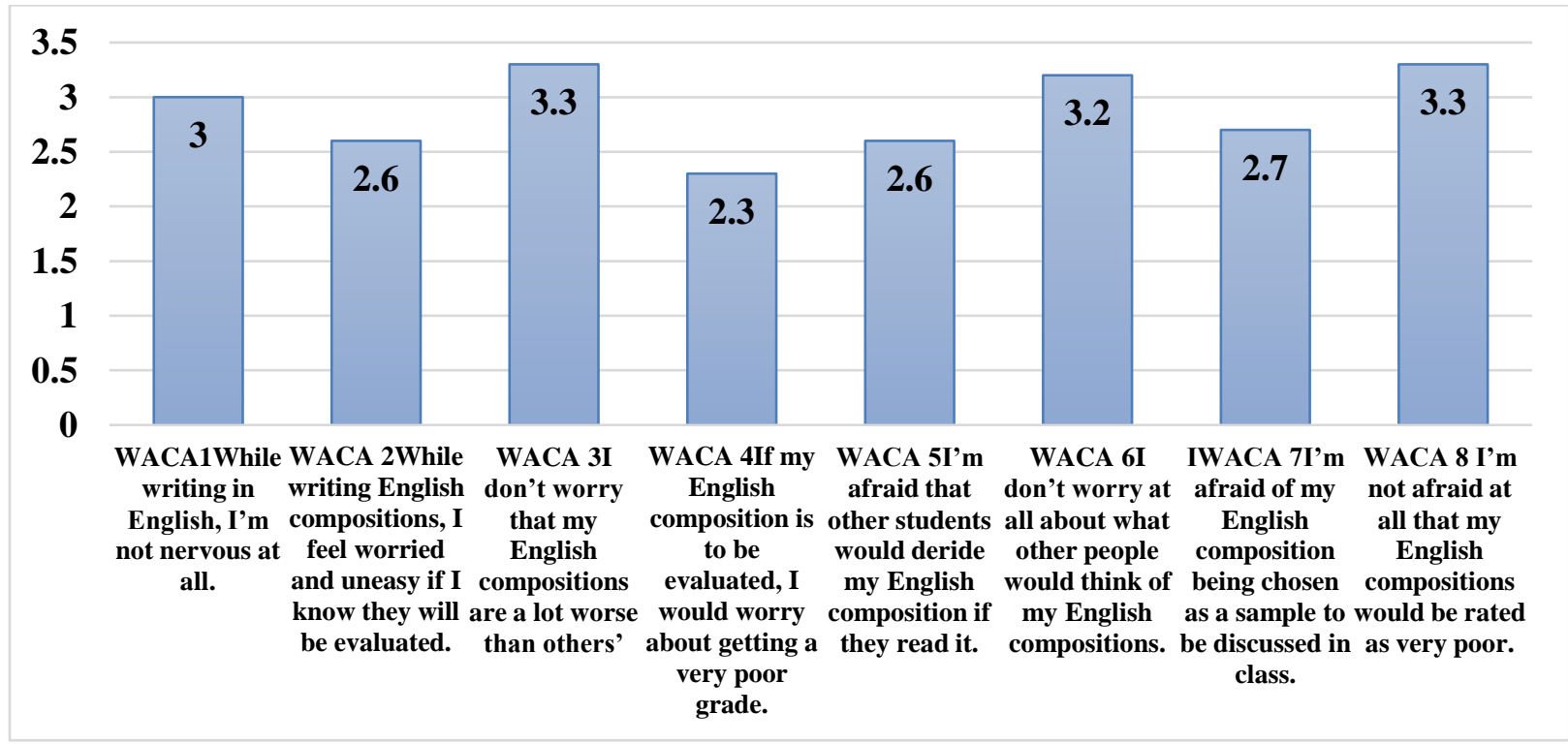

Figure 7: Mean Score for Cognitive Anxiety 
The mean score for cognitive anxiety is presented in figure 7 above. The highest mean is reported for two items. Respondents reported that they were not "worried if their English compositions were a lot worse than others". They were also not "afraid that their English compositions would be rated as very poor".

\subsection{Findings for Behaviour}

As a result of the expectations (the writing apprehension), the writer begins to (3) exhibit avoidance behaviour when it comes to writing-related activities.

\subsection{Writing Anxiety -Avoidance Behaviour Anxiety}

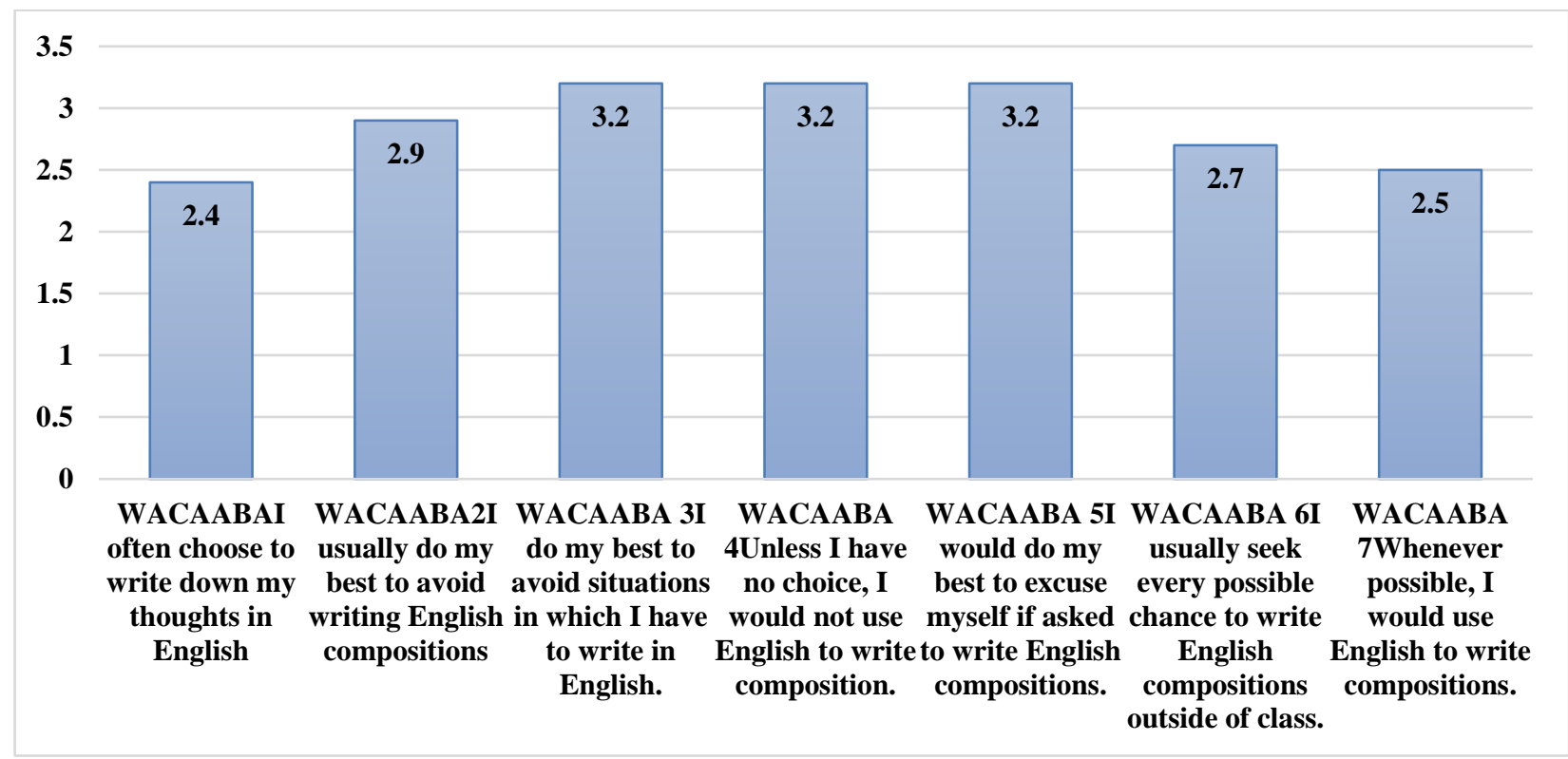

Figure 8: Mean Score for Avoidance Behaviour

Figure 8 above presents the findings for behaviour. The highest mean at 3.2 for three items. Respondents reported that they "did their best to avoid situations in which they had to write in English" unless "they had no choice, they would not sue English to write compositions". They also said they would "do their best to excuse themselves if they were asked to write English compositions".

\subsection{Findings for Results}

The last stage is result. This is the stage where the writer looks at his/her written task and reflect on the language use and writing process skills. Writers may face problems in (a) punctuation, (b) language use and (c) writing skills.

a) Problems-Punctuation 


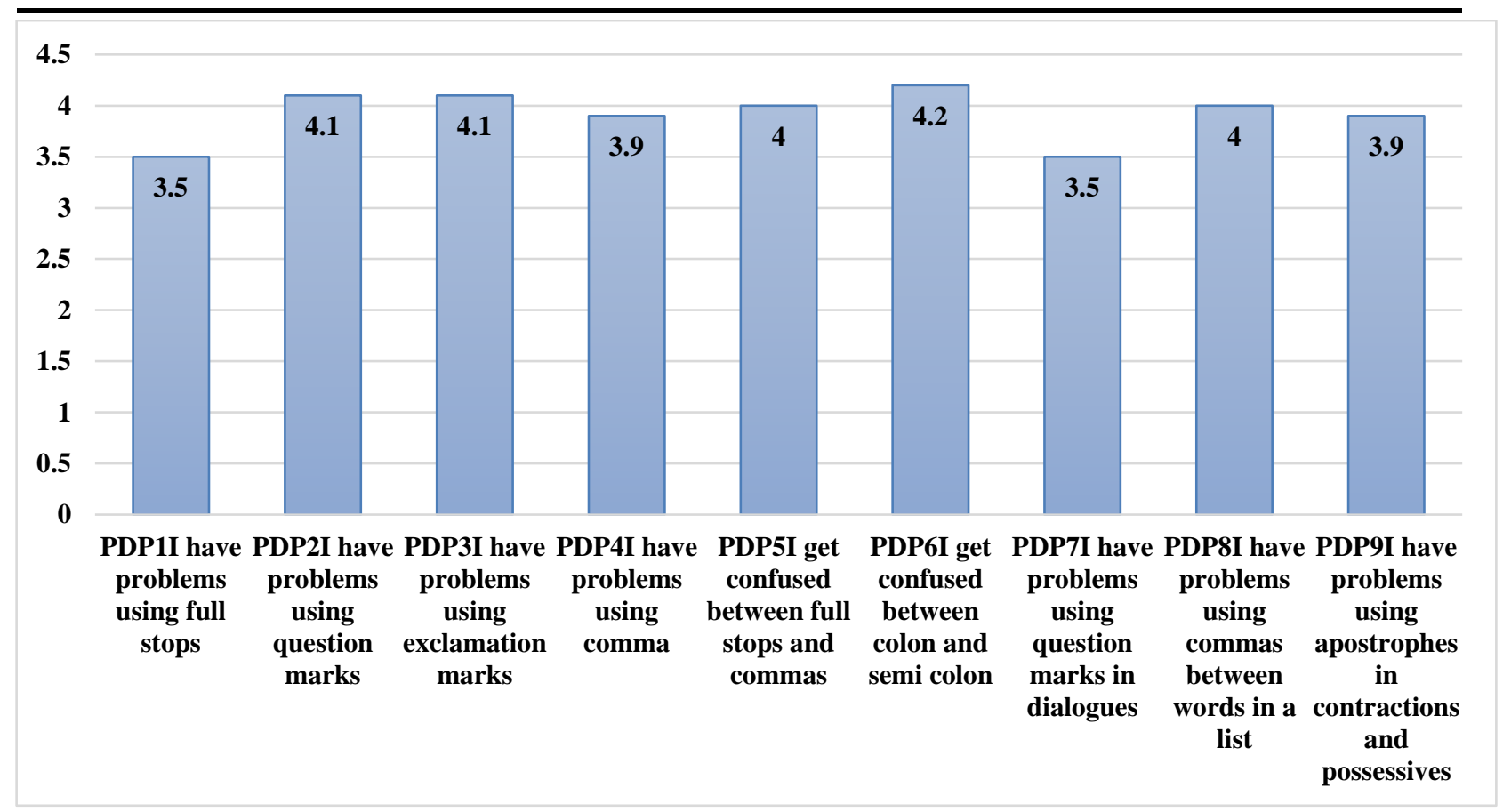

Figure 9: Mean Score for Problems (Punctuation)

Findings for problems in punctuations are presented in figure 9 above. The highest mean is 4.2 (writers are confused with colon nd semi-colon)The second highest mean is 4.1 for two items. Respondents reported that they "had problems using question marks and exclamation marks". Next, respondents reported that "they were confused the "fullstops and commas" (mean=4) and also " using commas between words in a list")mean=4).

b) Problems -Language Use

Findings for problems in language use is presented in figure 10 below. The highest mean at 3.6 is for " have problems using appropriate language in writing". Next at a mean of 3 is " have problems with the use of tenses". Respondents also reported that they "had problems with the use pf prepositions " (mean =2.9) and also "had problems in word order in the sentences" (mean=2.9) 


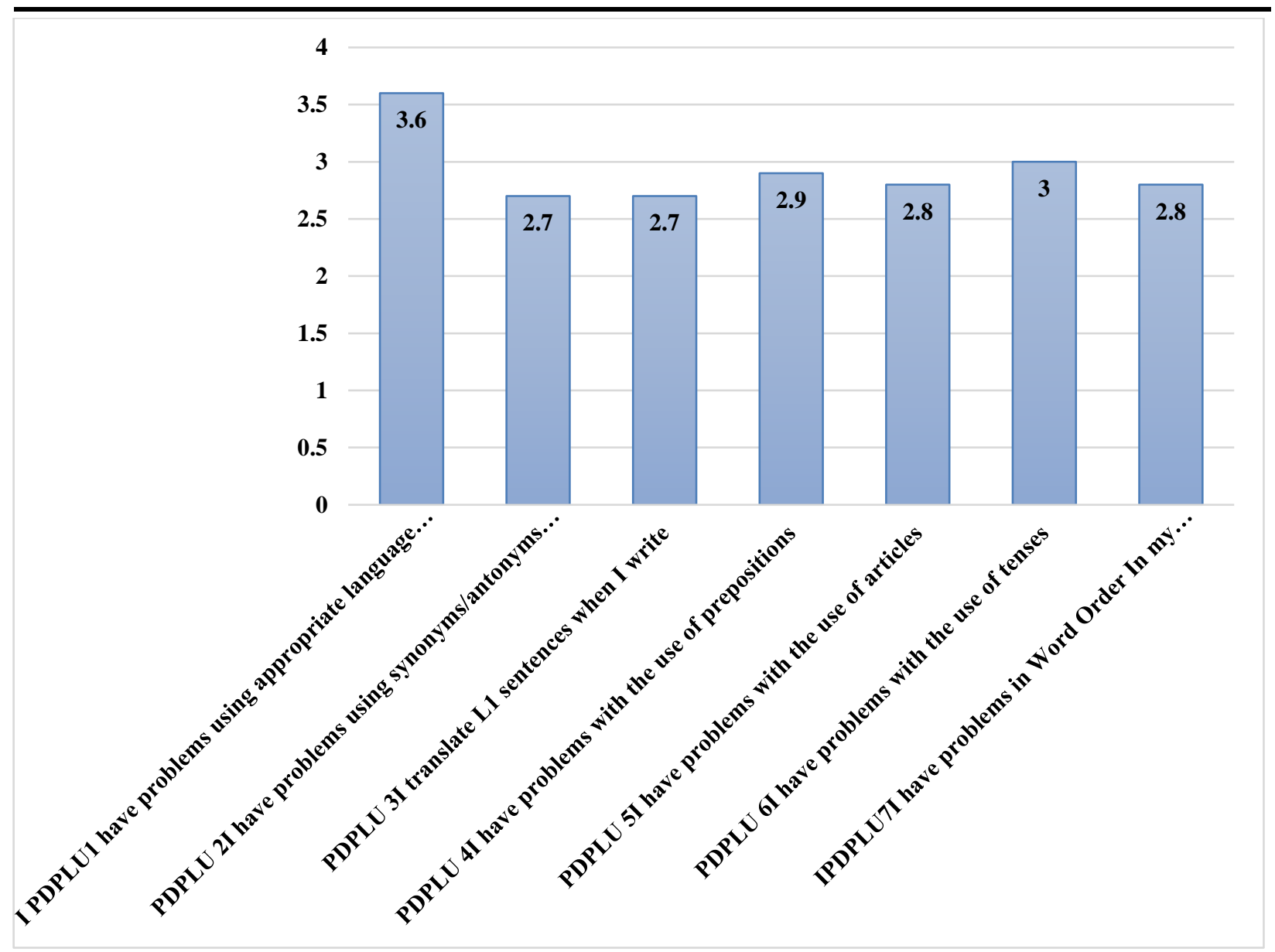

Figure 10: Mean Score for Problems (Language Use)

c) Problems -Writing Skills

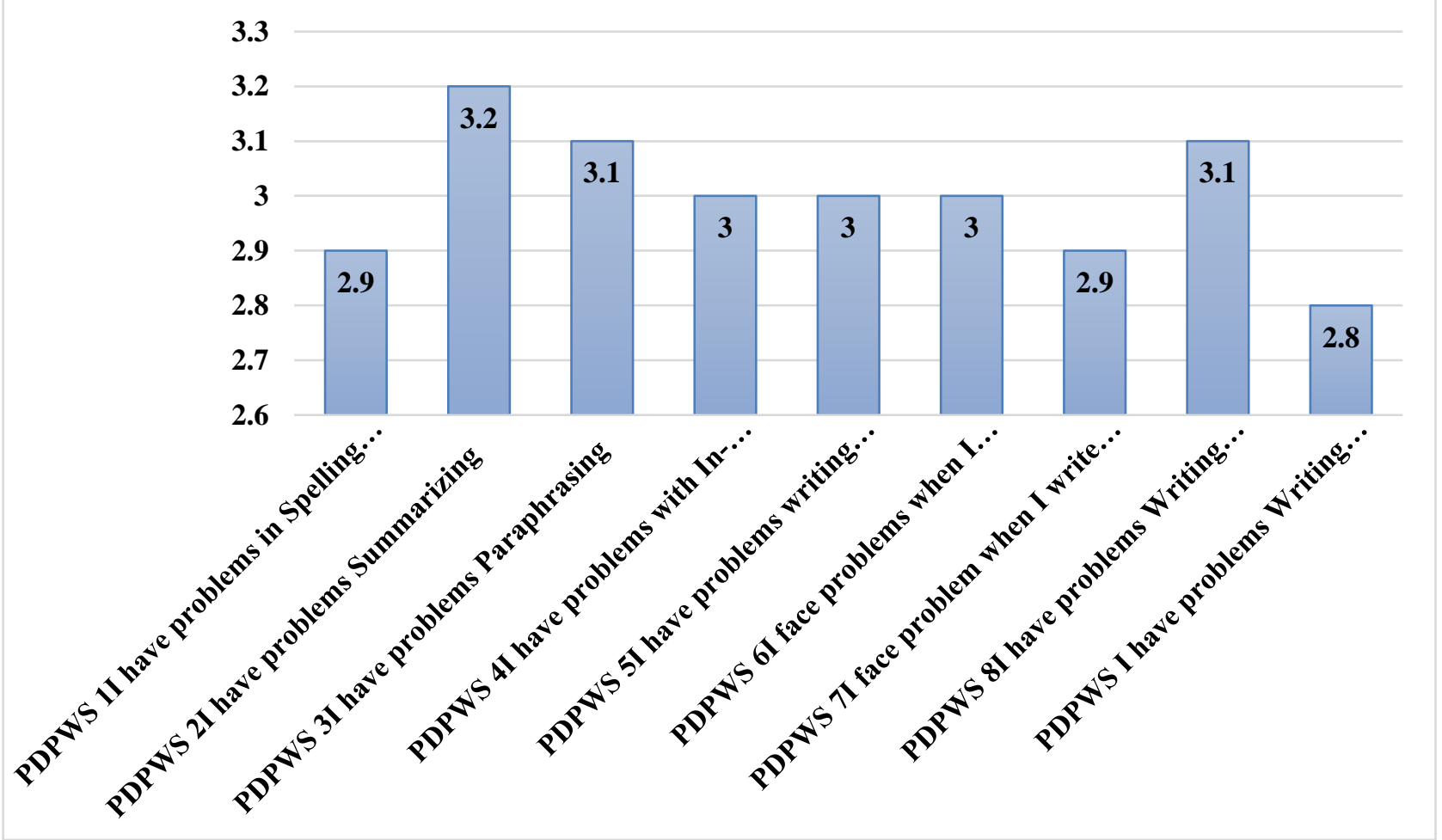

Figure 11: Mean Score for Problems (Writing Skill) 
Figure 11 presents the mean score for problems in writing skills. The highest mean is 3.2 for "problems summarizing". This is followed by "problems paraphrasing" (mean=3.1) and "have problems writing thesis statement "(mean =3.10). Participants also reported that they "had problems with in-text citations " (mean =3), "had problems writing end-of-text citations/referencing" (mean $=3$ _ and also "faced problems writing introductions" (mean=3)

\section{Conclusion}

\subsection{Summary of Findings and Implications}

This study reveals that one of the reasons why writers fear writing is that they have weak foundation in writing. Perhaps their past writing experience did not give them much to rely on for writing experiences. The study Shboul \& Huwari (2015) also revealed that past writing experiences play an important role toward their future writing experiences. Some learners blamed their writing teachers for their (the teachers') lack of interest in teaching writing to them They felt that the writing teachers need to use teaching methods that interest them. Shahbaz, Rabani, \& Noor (2021 also found that the teaching approach used (or not used) by the writing teachers can make a reluctant writer enjoy writing-related activities.

Next, in the cycle of writing prophecy, the beliefs and expectations that learners have about learning writing affects how they perceive the writing process. Respondents in this study reported that they were tensed when asked to write. They also had low esteem when it comes to writing. According to Badrasawi, Zubairi, \& Idrus (2016), writing apprehension can affects the writers' performance. If the writers do not address the fear, they may end up exhibiting avoidance behaviour when it comes to writing. This avoidance can further affect the learners' ability in writing. According to Fadda (2012), learners are weak in punctuations, language use and skills in the writing process. These skills can be improved by more practice. The problem is, is the learners avoid writing behaviour, the fear of writing becomes a never-ending cycle.

One way to break the cycle of writing fear is to take control of the starting point so the end points changes. With reference to figure 3, fear of writing begins with the writers' beliefs. The beliefs may stem from what the writer sees himself/herself as a writer and also how he/she perceives the writing teacher. If these beliefs can somehow be positive , then perhaps the writer can overcome his/her expectations and fear in a more positive manner. Fear will always be there. Some form of stress can make the learner achieve better. As a result of that, the writer would not display avoidance behaviour when it comes to writing. This can then lead to more positive result of the writing product. 


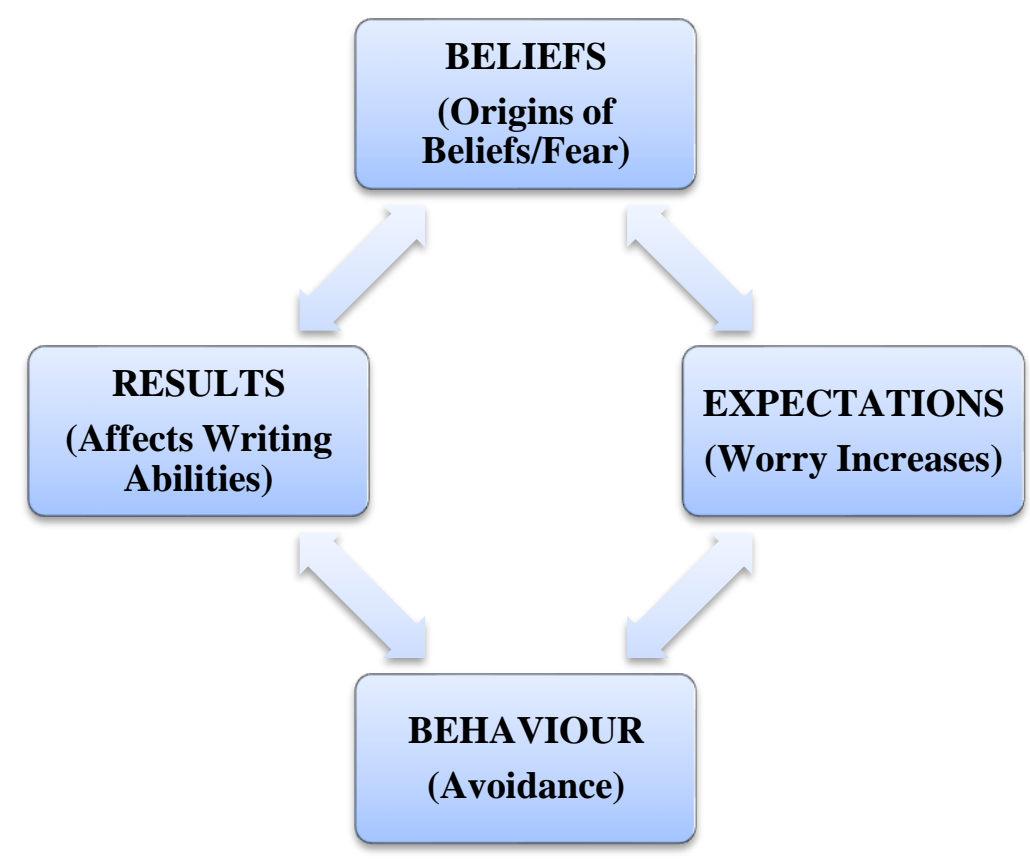

Figure 3: Conceptual Framework of the Study-Cycle of Writing Prophecy: Beliefs and Fear

\subsection{Pedagogical Implications and Suggestion for Future Research}

The teaching of writing has indeed changed over the years. Beside focussing on improving teaching methods, there is now a shift to add focus on the writers. According to Badraswai, Zubairi \& Idrus (2016), it is recommended that instructors should be more aware of students' problems in the writing skill and make plans to address the problems before teaching the writing process. In addition to that, Zhang (2019) also added that writing activities should include linguistic techniques to reduce students' anxieties in writing. It is suggested that future research could investigate writing apprehension differ across types of writing, categories of writers, or even writers of different disciplines.

\section{Acknowledgements}

The authors would like to thank the students who participated voluntarily in this study.

\section{Conflict of Interest Statement}

The authors declare no conflicts of interests.

\section{About the Authors}

Noor Hanim Rahmat has taught in the university for over 26 years. Her research interests are TESL, Educational Psychology, Academic Writing and Academic Reading.

Mazlen Arepin has taught in the university for more than 15 years. Her research interests include English Literature, TESL.

Norhartini Aripin has taught in the university for more than 6 years. Her research interests are TESL, Academic Writing, and Writing Anxiety.

Zarina Razlan has taught in the university for more than 10 years. Her research interests are TESL and Academic Writing. 


\section{References}

Al-Shboul, Y. \& Huwari, I. F. (2015). The Causes of Writing Apprehension through Students' Perspectives. Journal of Language Teaching and Research, Vol 6(3) ,pp 535-544. Retrieved from http://dx.doi.org/10.17507/jltr.0603.08

Badrasawi, K. J. I., Zubairi, A., \& Idrus, F. (2016). Exploring the Relationship between Writing Apprehension and Writing Performance: A Qualitative Study. International Education Studies, Vol ((8) pp 134-143. Retrieved from http://dx.doi.org/10.5539/ies.v9n8p134

Cheng, Y. S. (2004). A measure of second language writing anxiety: Scale development and preliminary validation. Journal of Second Language Writing, 13(4), 313335. Retrieved from https://eric.ed.gov/?id=EJ730641

Daly, J. A., \& Miller, M. D. (1975). Apprehension of writing as a predictor of message intensity. The Journal of Psychology, 89(2), 175-177. http://dx.doi.org/10.1080/00223980.1975.9915748

Fadda, H. A. (2012). Difficulties in Academic Writing: from the Perspective of King Saud University Postgraduate Students. English Language Teaching. Vol 593), pp 123130. Retrieved from https://files.eric.ed.gov/fulltext/EJ1078924.pdf

Klimova, B. F. (2014). Constraints and Difficulties in the Process of Writing Acquisition. Procedia Social and Behvioural Science 122(2014). $2^{\text {nd }}$ World Conference on Design, Arts and Education DAE-2013. Pp 433-437.

Marzec-Stawiarska, M. (2012). Foreign Language Writing Anxiety among Adult Advanced Learners of English. Linguistica Silesiana, Vol 33, pp 221-239. Retrieved from http://cejsh.icm.edu.pl/cejsh/element/bwmeta1.element.desklight-cbe87fd5$\underline{18 b 2-4 a 1 c-933 c}$

Merton, R. (1948). The Self-Fulfilling Prophecy. The Antioch Review, Vol 8(2), pp 193210. Retrieved from http://doi.org/10.2307/4609267

Rahmat, N. H. (2021). Writers' Beliefs and Expectations in Academic Writing: Towards a Model of Writing Prophecies. European Journal of English Language Teaching, Vol 6(4), pp 48-58. Retrieved from https://oapub.org/edu/index.php/ejel/article/view/3737

Rahmat, N. H. (2020). Investigating the Cycle of Fear in Foreign Language Learning. European Journal of Foreign Language Learning, Vol 5(1), pp 117-127. Retrieved from https://oapub.org/edu/index.php/ejfl/article/view/3245

Rahmat, N. H. (2019). Problems with Rhetorical Problems among Academic Writers. American Journal of Social Sciences and Humanities, Vol4(4), pp506-515. Retrieved from http://www.onlinesciencepublishing.com/welcome/htmlarticle/22/402/

Shahbaz, S., Rabani, M., Noor, M. (2021). Investigating English Language Speaking Anxiety and Writing Fear: A Case Study. Pakistan Social Sciences Review, Vol 5(2), pp 1089-1100. Retrieved from https://pssr.org.pk/issues/v5/2/investigatingenglish-language-speaking-anxiety-and-writing-fear-a-case-study.pdf 
Zhang, X. (2019). Exploring the relationship between college students' writing anxiety and the pedagogical use of online resources. Int J Educ Technol High Educ 16, 18 (2). https://doi.org/10.1186/s41239-019-0149-y.

Creative Commons licensing terms

Authors will retain the copyright of their published articles agreeing that a Creative Commons Attribution 4.0 International License (CC BY 4.0) terms will be applied to their work. Under the terms of this license, no permission is required from the author(s) or publisher for members of the community to copy, distribute, transmit or adapt the article content, providing a proper, prominent and unambiguous attribution to the authors in a manner that makes clear that the materials are being reused under permission of a Creative Commons License. Views, opinions, and conclusions expressed in this research article are views, opinions and conclusions of the author(s). Open Access Publishing Group and European Journal of English Language Teaching shall not be responsible or answerable for any loss, damage or liability caused in relation to/arising out of conflict of interests, copyright violations and inappropriate or inaccurate use of any kind content related or integrated on the research work. All the published works are meeting the Open Access Publishing requirements and can be freely accessed, shared, modified, distributed and used in educational, commercial and non-commercial purposes under a Creative Commons Attribution 4.0 International License (CC BY 4.0). 